Бондарева Василиса Евгеньевна

воспитатель

Черных Татьяна Анатольевна

воспитатель

МБДОУ Д/С №10 «Земский»

г. Белгород, Белгородская область

DOI $10.21661 / \mathrm{r}-554917$

\title{
МЕТОДИЧЕСКИЕ РЕКОМЕНДАЦИИ
}

ПО РАЗВИТИЮ ЭМОЦИОНАЛЬНОЙ СФЕРЫ

\section{У МЛАДШИХ ДОШКОЛЬНИКОВ СРЕДСТВОМ ИГРУШКИ}

Аннотация: данная работа посвящена вопросу развития эмочиональньий сферы младиих доикольников. Авторами предложены методические рекомендачзии по затрагиваемой теме.

Ключевые слова: эмочиональная сфера, развитие, младшие дошкольники.

Дошкольный возраст - это тот период, когда закладывается основа дошкольной жизни ребенка. Проблема эмоционального развития младших дошкольников является актуальной потому, что эмоциональный мир играет важную роль в жизни каждого человека. Этой проблемой занимались многие педагоги, психологи (Л.И. Божович, Л.С. Выготский, А.Н. Леонтьев, С.А. Рубинштейн, Т.А. Маркова, Я.З. Неверович, А.П. Усова, Д.Б. Эльконин, и др.), которые утверждали, что положительные эмоции создают оптимальные условия для активной деятельности мозга и являются стимулом для познания мира.

Эти эмоции участвуют в возникновении любой творческой деятельности ребенка, и конечно, в развитии его мышления. Тогда, как отрицательные эмоции заставляют избегать нежелательных или вредных действий, защищают и оберегают ребенка. Но следует заметить, что чрезмерное воздействие отрицательных эмоций разрушает мозг и психику человека. Если посмотреть на нашу повседневную жизнь, то можно увидеть, что от эмоций зависит наше отношение к людям, событиям, оценки собственных действий и поступков. 
Для этого образовательная и повседневная деятельность детей в младшей группе должна проходить в игровой и занимательной форме. Благодаря игровой деятельности, можно сконцентрировать внимание и привлечь интерес даже у несобранных детей. Вначале они увлекаются только игровыми действиями, а затем их начинает интересовать то, чему учит игра.

Организация игровой деятельности невозможна без достаточного количества различного игрового оборудования (игр, игрушек, спортивного инвентаря). Национальные нормы безопасности игрушек и методы их контроля, которые в полной мере соответствуют требованиям технического регламента о безопасности продукции, предназначенной для детей и подростков, установлены по стандартам ФГОС.

1. Во второй младшей группе, рекомендуется использовать игрушки, отражающие реальную жизнь, например:

- машина скорой помощи;

- грузовая, легковая машины;

- кукла-доктор и т. п.

2. Ряд игровых атрибутов нужно заменить предметами-заместителями для развития воображения ребенка, расширения творческих возможностей игры.

3. Необходимо размещать материалы на открытых полках, а сами материалы подбираются внешне привлекательные, яркие, и довольно часто их надо менять (не реже одного раза в неделю).

4. Все игрушки и пособия, находящиеся в группе, должны быть доступны для ребенка, это способствует развитию его активности, самостоятельности.

5. Игры с песком, водой, глиной, красками требуют специального оборудования это оборудование можно приобрести или сделать своими руками.

6. Из дидактических игр предпочтительны игры типа лото и парных картинок. Должны быть также:

- мозаика (крупная пластиковая, магнитная и крупная гвоздиковая), пазл из 3-15 частей, наборы кубиков из 4-12 штук;

- развивающие игры (например, «Сложи узор», «Сложи квадрат»); 
- игры с элементами моделирования и замещения;

- разнообразные «мягкие конструкторы» на ковролиновой основе позволяют организовать игру по - разному: сидя за столом, стоя у стены, лежа на полу.

Развитие эмоциональной сферы у детей дошкольного возраста немыслимо без использования занимательных игр, задач, развлечений. С детьми нужно играть. Детям интересно играть в сюжетно-ролевые, дидактические игры, они интересны для них, эмоционально захватывают детей. А процесс решения, поиска ответа, основанный на интересе к задаче, невозможен без активной работы мысли. Используя различные развивающие игры и упражнения в работе с детьми, можно понять, что, играя, дети лучше усваивают программный материал, правильно выполняют сложные задания.

Большое разнообразие игрушек используется для различных игровых тематик, ребенок не может постоянно играть в одно и то же. Игры могут быть:

- сюжетно-ролевые;

- подвижные;

- театрализованные;

- дидактические;

- строительные и другие.

Для младшего дошкольного созданы определенные игры, подобранные под их возрастные особенности, педагогика различает игры творческие, подвижные, дидактические.

7. К творческим играм относятся игры, в которых ребенок проявляет свою выдумку, инициативу, самостоятельность. Творческие проявления детей в играх разнообразны: от придумывания сюжета и содержания игры, поиска путей реализации замысла до перевоплощения в ролях, заданных литературным произведением. В зависимости от характера творчества детей, от игрового материала, используемого в играх, творческие игры делятся на режиссерские, сюжетно-ролевые, театрализованные, игры со строительным материалом.

Надо отметить, в традиционной педагогике режиссерские игры не выделялись в особый вид игровой деятельности, а рассматривались в русле сюжетно- 
ролевых игр. В последние годы складывается тенденция обособить режиссерские игры в связи с тем, что появились исследования, характеризующие их как самостоятельную разновидность сюжетно-ролевых игр. Основное отличие режиссерских игр состоит в том, что это преимущественно индивидуальные игры, в них ребенок управляет воображаемой ситуацией в целом, действует одновременно за всех участников.

8. Подвижные игры классифицируются по степени подвижности (игры малой, средней, большой подвижности), по преобладающим движениям (игры с прыжками, с перебежками и др.), по предметам, которые используются в игре (игры с мячом, с лентами, с обручами и др.).

Традиционно все дидактические игры можно разделить на три основных вида: игры с предметами (игрушками, природным материалом), настольно-печатные и словесные игры. 